\title{
Effect of sodium and nitrogen on yield function of irrigated maize in southern Portugal
}

\author{
T.B. Ramos ${ }^{a, *}$, M.C. Gonçalves ${ }^{a}$, N.L. Castanheira ${ }^{b}$, J.C. Martins ${ }^{a}$, \\ F.L. Santos ${ }^{b}$, A. Prazeres ${ }^{a}$, M.L. Fernandes ${ }^{a}$ \\ a Instituto Nacional de Recursos Biológicos, L-INIA, Estação Agronómica Nacional, Av. República, \\ Quinta do Marquês, 2784-505 Oeiras, Portugal \\ ${ }^{\mathrm{b}}$ Rural Engineering Department, ICAM, University of Évora, Apartado 94, 7002-554 Évora, Portugal
}

\section{A R T I C L E I N F O}

Article history:

Received 18 April 2008

Accepted 26 September 2008

Published on line 6 November 2008

Keywords:

Salinity

Fertilization

Crop production

Mediterranean region

\begin{abstract}
A B S T R A C T
Salinization and nitrate leaching are two of the leading threats to the environment of the European Mediterranean regions. Inefficient use of water and fertilizers has led to a nitrate increase in the aquifers and reduction in crop yields caused by salts. In this study, a triple emitter source irrigation system delivers water, salt $\left(\mathrm{Na}^{+}\right)$, and fertilizer $(\mathrm{N})$ applications to maize (Zea mays L.). The objective of the study was to evaluate the combined effect of saline water and nitrogen application on crop yields in two different textured soils of Alentejo (Portugal) and to assess if increasing salinity levels of the irrigation water can be compensated by application of nitrogen while still obtaining acceptable crop yield. Maximum yield was obtained from both soils with an application of $13 \mathrm{~g} \mathrm{~m}^{-2}$ of nitrogen. Yield response to $\mathrm{Na}^{+}$application was different in the two studied soils and depended on the total amount of $\mathrm{Na}^{+}$or irrigation water applied. No significant interaction was found between nitrogen and sodium, but a positive effect on maize yield was observed in the medium textured soil for amounts of $\mathrm{Na}^{+}$less than $905 \mathrm{~g} \mathrm{~m}^{-2}$ when applied in the irrigation water.
\end{abstract}

(C) 2008 Elsevier B.V. All rights reserved.

\section{Introduction}

In the Portuguese southern region of Alentejo, irrigated agriculture is the most important farm enterprise. Water is the key factor limiting crop production. Mediterranean conditions prevail with hot summers and scarce rainfall, and with mild and rainy winters. Because of arid conditions, hundreds of thousands of hectares have been converted to irrigation in the last years. Improving crop productivity by using water and nutrients more efficiently has been the leading research approach for the region. Field experiments were conducted to measure the effects and interaction of water and fertilizer input on grain yields of major crops such as maize (Zea mays L.), sugar beet (Beta vulgaris L.), tomato
(Lycopersicum esculentum Miller), potato (Solanum tuberosum L.), and lettuce (Lactuca sativa L.) (Ramos et al., 1996; Beltrão et al., 2002a).

Inefficient usage of water and fertilizers has led to an increase in nitrate $\left(\mathrm{NO}_{3}{ }^{-}\right)$levels in the aquifers of the region. Since the 1970s, a steady increase in nitrate levels has been recorded at shallow depths. Currently, the European legislation 91/676/CEE limits the level of nitrate permissible in waters used for human consumption. Waters from aquifers of some irrigated areas have reached threshold values. As a result, such water can no longer be used for human consumption. Furthermore, a considerable degree of caution must be exercised when using such waters for irrigation (Duque and Almeida, 1998). As a result, only limited fertilizer application is

\footnotetext{
* Corresponding author. Tel.: +351 214403500; fax: +351 214416011.

E-mail address: tiago_ramos@netcabo.pt (T.B. Ramos). 
permissible in some of the most important agricultural areas of Alentejo.

Compounding the problem, electrical conductivity (EC) values of $0.4-2.6 \mathrm{dS} \mathrm{m}^{-1}$ have been recorded in collective irrigation water reservoirs of the region in the past years. In addition, values between 0.7 and $3.0 \mathrm{dS} \mathrm{m}^{-1}$ have commonly been found in the small private water reservoirs located in the farmers' fields throughout the region (Oliveira and Varela, 2005). Waters that are generally classified according to the U.S. Salinity Laboratory (Richards, 1954) as medium $\left(C_{2}\right)$ to high $\left(C_{3}\right)$ salinity and of low sodification $\left(S_{1}\right)$ risk present a soil salinization hazard and may cause significant reduction in yield for a large number of crops, especially vegetables and fruits (Ayers and Westcot, 1985; Mass, 1990; Steppuhn et al., 2005). Salinization by irrigation water is a process whereby soluble salts from the irrigation water accumulate in the soil due to inadequate leaching, high water tables and/or high evaporation rates. Soil salinity affects plants directly through osmotic effects, which limit the ability of the plants to absorb water from the soil solution. Specific ion effects and changes in soil physical and chemical properties can have long-term detrimental effects on crop production (Keren, 2000). If the salts are primarily sodic salts, as is frequently the case, their accumulation increases the concentration of sodium ions in the soil exchange complex, affecting soil properties and behaviour. Thus, salinity can also have an indirect effect on plant growth through deleterious modification of soil properties such as swelling, and porosity, water retention and permeability changes (Hillel, 1998).

Currently, protecting the natural resources is of more concern than optimising crop production. Soil and water resource conservation are the key priorities of agricultural research for European regions like Alentejo. Soil salinization/ sodification and nitrate leaching to aquifers are two of the leading threats to the environment of the region. Study of the combined effects of saline water and nitrogen application on the yield function could give answers about how to overcome the soil salinization/sodification process and how to reduce nitrate leaching in areas where irrigation water is of poor quality. Crop yield-water consumption relationships at certain fertility levels have been widely examined in a variety of water management studies (Ramos et al., 1996; Kipkorir et al., 2002; Brumbelow and Georgakakos, 2007; Liu and Zhang, 2007; Igbadun et al., 2007). However, many production function studies have been limited to non-saline water. Very few studies exist for crop response under saline conditions. In cases of poor water quality, the level of sodium content in water should be considered as a third factor because sodium content strongly affects crop production (Dinar et al., 1991; Datta et al., 1998; Beltrão et al., 2002a).

Despite a large number of studies demonstrate that salinity reduces nutrient uptake and affects nutrient partitioning within the plant, little evidence exists that adding nutrients at levels above the optimal levels in non-saline environments improves crop yield (Grattan and Grieve, 1999). In fact, several studies show that at high-salinity levels, increasing $\mathrm{N}$ is ineffective in counteracting adverse effects of increased salt concentrations on growth and yield (Papadopoulos and Rending, 1983; Makus, 2003; Villa-Castorena et al., 2003). However, other studies also show that $\mathrm{N}$ applications can be beneficial in reducing the detrimental effects of salinity by partial substitution of $\mathrm{NO}_{3}{ }^{-}$with $\mathrm{NH}_{4}{ }^{+}$. Furthermore $\mathrm{N}$ applications can be beneficial due to the lower energy cost of $\mathrm{N}$ assimilation with $\mathrm{NH}_{4}{ }^{+}$as compared to $\mathrm{NO}_{3}{ }^{-}$administration (Sandoval-Villa et al., 1999; Flores et al., 2001; Kant et al., 2007).

The objective of this study was to evaluate the combined effects of saline water and nitrogen application on maize (Zea mays L.) yield function in two different soils of Alentejo (Portugal) and to assess if increased salinity levels of the irrigation water can be compensated by application of nitrogen while still obtaining acceptable yields.

\section{Materials and methods}

\subsection{Site description}

Field plot experiments were conducted at the Alvalade Experimental Station $\left(37^{\circ} 56^{\prime} 48^{\prime \prime} \mathrm{N}\right.$ and $\left.8^{\circ} 23^{\prime} 40^{\prime \prime} \mathrm{W}\right)$, and at the Herdade da Mitra of the University of Évora $\left(38^{\circ} 31^{\prime} 55^{\prime \prime} \mathrm{N}\right.$ and $\left.8^{\circ} 00^{\prime} 59^{\prime \prime} \mathrm{W}\right)$, both located in southern Portugal, in the Alentejo region. The soil chemical, physical and hydraulic properties of both soils were measured in the beginning of the experiments.

In Alvalade, the experiments were performed on a field with Eutric Fluvisol soil (WRB, 2006). In the top $30 \mathrm{~cm}$, particle sizes between 2000 and $200 \mu \mathrm{m}$ (coarse sand), 200 and $20 \mu \mathrm{m}$ (fine sand), 20 and $2 \mu \mathrm{m}$ (silt), and less than $2 \mu \mathrm{m}$ (clay) were, according to the Atterberg scale, 8.3, 52.4, 26.3, and 13.0 wt.\%, respectively, corresponding to a loam soil. Dry bulk density $(\rho)$ was $1.49 \mathrm{~g} \mathrm{~cm}^{-3}$, total porosity was $39.2 \mathrm{vol} . \%$, the field capacity and wilting point were 31.0 and $9.8 \mathrm{vol} \%$, respectively, and the saturated hydraulic conductivity was $14.2 \mathrm{~cm} \mathrm{~d}^{-1}$. The $\mathrm{pH}\left(\mathrm{H}_{2} \mathrm{O}\right)$ was 7.0 , the average organic matter was $26.5 \mathrm{~g} \mathrm{~kg}^{-1}$, and total nitrogen, available phosphorus, and potassium were, respectively, $1.15 \mathrm{~g} \mathrm{~kg}^{-1}$, and 131 and $100 \mathrm{mg} \mathrm{kg}^{-1}$. Cation exchange capacity (CEC) was $13.59 \mathrm{cmol}_{\mathrm{C}} \mathrm{kg}^{-1}$, Electrical conductivity of the saturation extract was $0.42 \mathrm{dS} \mathrm{m}^{-1}$, and the exchangeable sodium percentage (ESP) was $2.06 \%$.

In Mitra, the field experiments were carried out on a Hortic Antrosol (WRB, 2006). Also in the top $30 \mathrm{~cm}$, particle sizes between 2000 and $200 \mu \mathrm{m}, 200$ and $20 \mu \mathrm{m}, 20$ and $2 \mu \mathrm{m}$, and less than $2 \mu \mathrm{m}$ were $46.1,35.9,10.1$, and $7.9 \mathrm{wt} . \%$, respectively, thus classifying the soil as a sandy loam textural class. Dry bulk density $(\rho)$ was $1.51 \mathrm{~g} \mathrm{~cm}^{-3}$, total porosity was 36.0 vol.\%, the field capacity and wilting point were 22.3 and 9.9 vol.\%, respectively, and the saturated hydraulic conductivity was $42.3 \mathrm{~cm} \mathrm{~d}^{-1}$. The $\mathrm{pH}\left(\mathrm{H}_{2} \mathrm{O}\right)$ was 6.6 , the average organic matter was $33.3 \mathrm{~g} \mathrm{~kg}^{-1}$, and total nitrogen, available phosphorus and potassium were, respectively, $1.28 \mathrm{~g} \mathrm{~kg}^{-1}$, and 458 and $118 \mathrm{mg} \mathrm{kg}^{-1}$, respectively. CEC was $13.72 \mathrm{cmol}_{\mathrm{C}} \mathrm{kg}^{-1}$, EC of the saturation extract was $0.48 \mathrm{dS} \mathrm{m}^{-1}$, and ESP was $0.63 \%$.

\subsection{Climate and water application}

The experiments were conducted from 2004 to 2006. Fig. 1 shows the monthly precipitation collected at Alvalade and Mitra meteorological stations, and the reference evapotranspiration rate $\left(\mathrm{ET}_{0}\right)$ determined from the collected meteorological data by the Penman-Monteith method (Allen et al., 

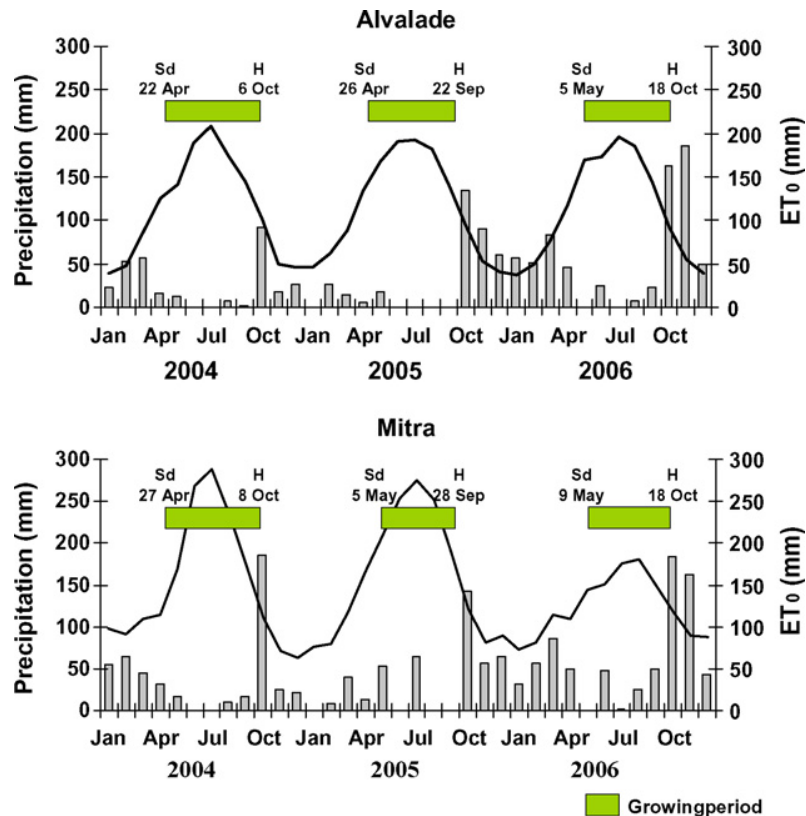

Fig. 1 - Monthly precipitation ( $\mathrm{mm}$ ), and monthly reference evapotranspiration rate $(\mathrm{mm})$, for the period of 2004-2006. Sd and $\mathrm{H}$ correspond to the sowing and harvest dates, respectively.

1998) during the 3 years of the experiment. The climate in both experimental areas is mostly dry sub-humid, with hot dry summers, and mild winters with irregular rainfall. $\mathrm{ET}_{0}$ in Alvalade presented values between 859 and $873 \mathrm{~mm}$ during the growing seasons (May-September) of the 3 years period, while in Mitra the $\mathrm{ET}_{0}$ varied between 801 and $1181 \mathrm{~mm}$.

In the 3 years of the experiment, precipitation was very low during the crop cycle, which corresponded with the time of the year when the evaporative demands of the atmosphere were higher and crop water needs had to be fulfilled by irrigation, as it is common in the summer season under Mediterranean conditions. Years 2004 and 2005 were extremely dry with higher reference evapotranspiration values than average, especially in the most water sensitive stages of crop development, in late July and August. The total amount of water applied during the 3 years of the experiment is presented in Table 1. Experimental fields were irrigated three times per week between June and September. In Alvalade, application amounts averaged $23 \mathrm{~mm}$ per irrigation event while in Mitra the mean application amount was $18 \mathrm{~mm}$ per irrigation event. In July, nitrogen fertilization was applied in both experimental fields in five irrigation events during the vegetative stage.

Table 1 - Total amount of water applied in Alvalade, and Mitra during the three irrigation seasons of the experiment.

\begin{tabular}{lrrr} 
Experimental field & \multicolumn{3}{c}{ Water applied (mm) } \\
\cline { 2 - 4 } & 2004 & 2005 & 2006 \\
\hline Alvalade & 997 & 1012 & 1028 \\
Mitra & 1067 & 725 & 729 \\
\hline
\end{tabular}

\subsection{Experimental design and treatments}

Multifactorial experiments require complex designs and large experimental areas. Such experiments are very time consuming and expensive. To significantly reduce the cost and size of the experimental area, sprinkler single-line (Hanks et al., 1976; Lauer, 1983; Magnusson et al., 1989; Levy et al., 1999), doubleline (de Malach et al., 1996), crossed triple-line (Magnusson and Ben Asher, 1990), and triple-line source methods (Beltrão et al., 2002b) have been used instead. The layouts of these systems were tested in salinity and fertilization experiments on several crops and in small areas to produce mixing between the maximal and minimal concentrations of the required production factors. When the mixing gradations were arranged in a sequential order, the results showed that gradual changes of salinity were well distributed throughout the experimental layout.

A triple emitter source irrigation system was used in this experiment to deliver water, salt $\left(\mathrm{Na}^{+}\right)$, and fertilizer (N) applications to the crop. This system, adapted from Beltrão et al. (2002b), consists of three trickle laterals connected together in order to form a triple joint lateral. The first of the laterals was connected to the salt stock solution while the second one was connected to the nitrogen reservoir. The third lateral delivered fresh water and was used to obtain a constant water application rate for each dripping point along the triple joint lateral. Gradients of applied salt $\left(\mathrm{Na}^{+}\right)$and nitrogen $(\mathrm{N})$ concentration were produced by placing different emitters along the laterals and varying their discharge rate to obtain various mixtures between the three lines. A constant application rate was maintained at each dripping point.

Each experimental field (Fig. 2) was divided into four groups (I-IV) with three triple joint laterals each, establishing a $\mathrm{N}$ gradient decreasing from groups I-IV. Each group was then divided into three treatment areas, A-C, each with surface area of $6.75 \mathrm{~m}^{2}$ (2.25 m wide $\times 3 \mathrm{~m}$ long), and with the $\mathrm{Na}^{+}$ gradient decreasing from $\mathrm{A}-\mathrm{C}$. The dripping points were spaced $1 \mathrm{~m}$ apart, with a total of nine emitters in each of the 12 treatment areas. Two laterals of fresh water bordered the different groups. Each treatment area was bordered with earthen ridges, which prevented surface runoff from crossing over during rainfall and irrigation.

The overall discharge of a dripping point $Q_{i}$, at different locations of the $j$ th triple joint lateral (where $i=m$ and $j=n$ ) was maintained constant, at $18 \mathrm{~L} / \mathrm{h}$ in all 12 treatments, but with variations in the discharge of the emitters located at each single triple point line of salt $q \mathrm{~S}_{i, j}\left(\mathrm{Na}^{+}\right)$, nitrogen $q \mathrm{~N}_{i, j}(\mathrm{~N})$ and fresh water $q \mathrm{~W}_{i, j}$, delivering system as:

$Q_{i, j}=q S_{i, j}+q N_{i, j}+q W_{i, j}$

The mass of each solute $\mathrm{MS}_{\mathrm{i}, \mathrm{j}}\left(\mathrm{Na}^{+}\right)$and $\mathrm{MN}_{i, j}(\mathrm{~N})$ applied at each ith dripping point located at the jth triple joint lateral is obtained as:

$\mathrm{MS}_{i, j}=q \mathrm{~S}_{i, j} \mathrm{CS}_{i, j}$

$\mathrm{MN}_{i, j}=q \mathrm{~N}_{i, j} \mathrm{CN}_{i, j}$ 


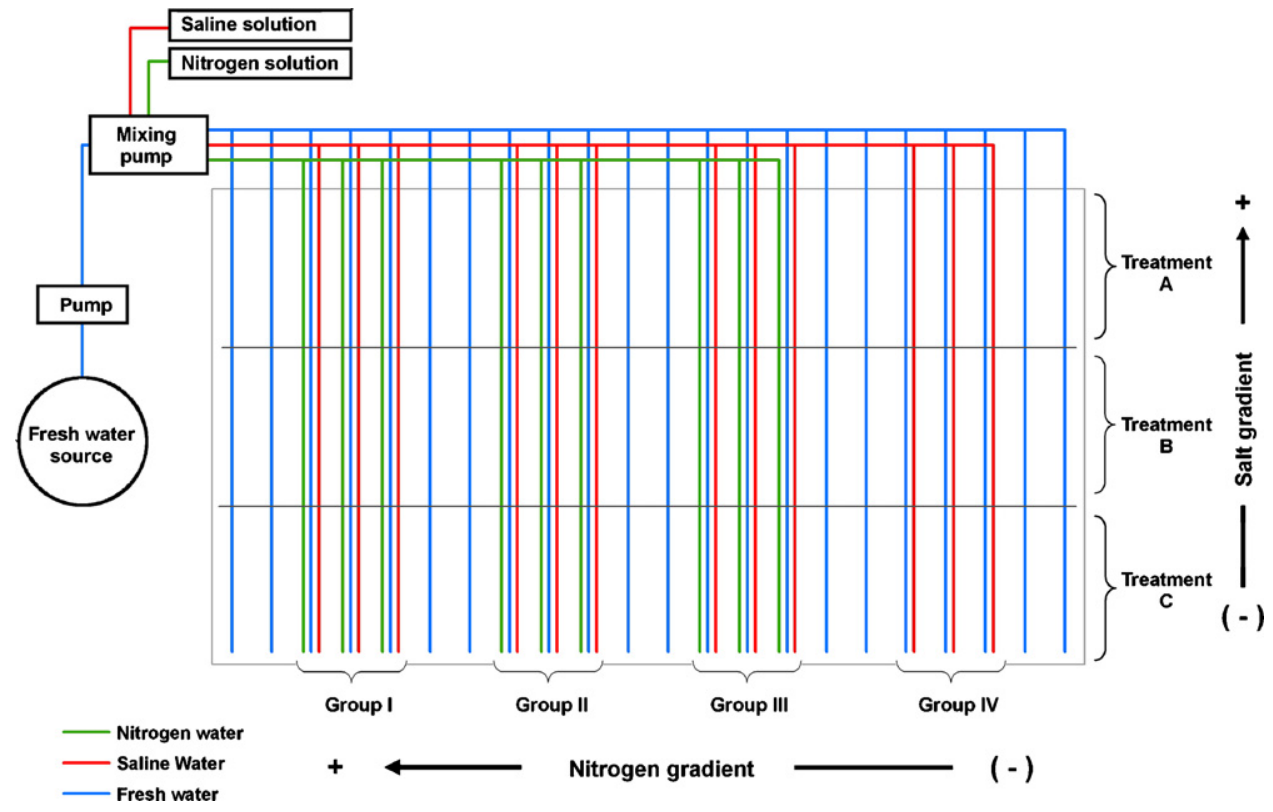

Fig. 2 - Layout of the triple emitter source design. The salt gradient decreases from Treatments A-C and the fertilizer gradient decreases from groups I-IV.

where $\mathrm{CS}_{i, j}$ and $\mathrm{CN}_{i, j}$, the $\mathrm{Na}^{+}$and $\mathrm{N}$ concentrations at each ith dripping point and $j$ th triple joint lateral, respectively, were calculated as:

$\mathrm{CS}_{i, j}=\frac{\mathrm{MS}_{i, j}}{\mathrm{Q}_{i, j}}$

$\mathrm{CN}_{i, j}=\frac{\mathrm{MN}_{i, j}}{\mathrm{Q}_{i, j}}$

The discharges of the emitters along the triple joint laterals are presented in Table 2.

The concentration of saline and the applied fertilizer waters in all salt and nitrogen laterals was constant in each year. However, different emitter discharges from the laterals resulted in different applied amounts of $\mathrm{N}$ and $\mathrm{Na}^{+}$in all plots of the four groups. The amount of applied $\mathrm{N}$ and $\mathrm{Na}^{+}$in all groups and treatments is described in Table 3.

\subsection{Relationship between applied factors and yield function analysis}

At the end of each crop cycle, grain yield and interrelationship with applied factors (nitrogen and sodium) were evaluated. By multiple stepwise regression analysis, it was determined that at Alvalade and Mitra grain yield was related to the total amount of salt $\left(\mathrm{Na}^{+}\right)$, nitrogen $(\mathrm{N})$ and water $(\mathrm{W})$ applied during the irrigation cycles. In the process, two dummy variables were introduced as orthogonal polynomial coefficients to take into account the two types of soil (Soil) and each year of the experiment (Year). The results from the two experimental fields were analysed in cluster as well as separately by field plot.

\section{Results}

Mean grain yield of the individual treatments and the standard deviations of the three repetitions for each experimental field are presented in Table 4.

Table 2 - Discharge rates of the laterals applying salt $\left(\mathrm{Na}^{+}\right)$, nitrogen $(\mathrm{N})$ and fresh water $(\mathrm{W})$ in experimental plots. The emitters on the three coupled lines have different discharges, resulting in different salt and nitrogen concentrations. A constant cumulative discharge rate of $18 \mathrm{~L} / \mathrm{h}$ was used at each dripping point.

Treatment Application rates $(\mathrm{L} / \mathrm{h})$

\begin{tabular}{|c|c|c|c|c|c|c|c|c|c|c|c|c|}
\hline & \multicolumn{3}{|c|}{ Group I } & \multicolumn{3}{|c|}{ Group II } & \multicolumn{3}{|c|}{ Group III } & \multicolumn{3}{|c|}{ Group IV } \\
\hline & $\mathrm{Na}^{+}$ & $\mathrm{N}$ & W & $\mathrm{Na}^{+}$ & $\mathrm{N}$ & $\mathrm{W}$ & $\mathrm{Na}^{+}$ & $\mathrm{N}$ & W & $\mathrm{Na}^{+}$ & $\mathrm{N}$ & W \\
\hline A & 12 & 6 & 0 & 12 & 4 & 2 & 12 & 2 & 4 & 12 & 0 & 6 \\
\hline B & 6 & 6 & 6 & 6 & 4 & 8 & 6 & 2 & 10 & 6 & 0 & 12 \\
\hline C & 0 & 6 & 12 & 0 & 4 & 14 & 0 & 2 & 16 & 0 & 0 & 18 \\
\hline
\end{tabular}




\begin{tabular}{|c|c|c|c|c|c|c|c|c|c|c|c|c|c|}
\hline \multirow[t]{3}{*}{ Group } & \multirow[t]{3}{*}{$\operatorname{Tr}$. } & \multicolumn{6}{|c|}{ Salt $\left(\mathrm{g} \mathrm{m}^{-2}\right)$} & \multicolumn{6}{|c|}{ Nitrogen $\left(\mathrm{g} \mathrm{m}^{-2}\right)$} \\
\hline & & \multicolumn{2}{|c|}{2004} & \multicolumn{2}{|c|}{2005} & \multicolumn{2}{|c|}{2006} & \multicolumn{2}{|c|}{2004} & \multicolumn{2}{|c|}{2005} & \multicolumn{2}{|c|}{2006} \\
\hline & & Alv. & Mit. & Alv. & Mit. & Alv. & Mit. & Alv. & Mit. & Alv. & Mit. & Alv. & Mit. \\
\hline \multirow[t]{3}{*}{ I } & A & 1365 & 1352 & 2055 & 962 & 2792 & 1229 & 19 & 9 & 20 & 15 & 22 & 21 \\
\hline & B & 683 & 676 & 1027 & 481 & 1396 & 614 & 19 & 9 & 20 & 15 & 22 & 21 \\
\hline & $\mathrm{C}$ & 0 & 0 & 0 & 0 & 0 & 0 & 19 & 9 & 20 & 15 & 22 & 21 \\
\hline \multirow[t]{3}{*}{ II } & A & 1365 & 1352 & 2055 & 962 & 2792 & 1229 & 13 & 6 & 13 & 10 & 15 & 14 \\
\hline & B & 683 & 676 & 1027 & 481 & 1396 & 614 & 13 & 6 & 13 & 10 & 15 & 14 \\
\hline & $\mathrm{C}$ & 0 & 0 & 0 & 0 & 0 & 0 & 13 & 6 & 13 & 10 & 15 & 14 \\
\hline \multirow[t]{3}{*}{ III } & A & 1365 & 1352 & 2055 & 962 & 2792 & 1229 & 6 & 3 & 7 & 5 & 7 & 6 \\
\hline & B & 683 & 676 & 1027 & 481 & 1396 & 614 & 6 & 3 & 7 & 5 & 7 & 6 \\
\hline & $C$ & 0 & 0 & 0 & 0 & 0 & 0 & 6 & 3 & 7 & 5 & 7 & 6 \\
\hline \multirow[t]{3}{*}{ IV } & A & 1365 & 1352 & 2055 & 962 & 2792 & 1229 & 0 & 0 & 0 & 0 & 0 & 0 \\
\hline & B & 683 & 676 & 1027 & 481 & 1396 & 614 & 0 & 0 & 0 & 0 & 0 & 0 \\
\hline & $C$ & 0 & 0 & 0 & 0 & 0 & 0 & 0 & 0 & 0 & 0 & 0 & 0 \\
\hline
\end{tabular}

\subsection{Yield response curves at Alvalade}

From the result of the multiple stepwise regression analysis between grain yield $(\mathrm{Y})$ and the input factors nitrogen $(\mathrm{N})$, salt $\left(\mathrm{Na}^{+}\right)$, water $(\mathrm{W})$, and their interactions at Alvalade for the period of 2004-2006 (Year), the following relationship was established:

$\mathrm{Y}_{\text {Alvalade }}=804.98+43.46 \mathrm{Year}+43.35 \mathrm{~N}-1.6075 \mathrm{~N}^{2}$

$$
+0.1575 \mathrm{Na}^{+}-0.000087\left(\mathrm{Na}^{+}\right)^{2}
$$

The analysis of variance for Eq. (6) indicates a sum of squares due to regression (SSR) of $8.187 \times 10^{5}$, a sum of squares due to error (SSE) of $4.950 \times 10^{5}$, a determination coefficient $\left(R^{2}\right)$ of 0.623 , a $F$-value of 9.92, and $P<0.0001$ for $n=36$ observations. Fig. 3 shows the response curves of yield to different levels of $\mathrm{N}$ and $\mathrm{Na}^{+}$at Alvalade.

\subsection{Yield response curves at Mitra}

From the result of the multiple stepwise regression analysis between grain yield $(\mathrm{Y})$ and the input factors nitrogen $(\mathrm{N})$, salt $\left(\mathrm{Na}^{+}\right)$, water $(\mathrm{W})$, and their interactions at Mitra for the period of 2004-2006 (Year), the following relationship was established

$$
Y_{\text {Mitra }}=572.73+89.45 \text { Year }+51.55 \mathrm{~N}-1.9562 \mathrm{~N}^{2}
$$$$
-0.5898 \mathrm{Na}^{+}+0.000649 \mathrm{~W} \mathrm{Na}^{+}
$$

The analysis of variance for Eq. (7) shows a SSR of $1.430 \times 10^{6}$, a SSE of $0.562 \times 10^{6}$, a $R^{2}$ of 0.718 , a F-value of 15.25 , and $P<0.0001$ for $n=36$ observations. Fig. 4 shows the response curves of yield to different levels of $\mathrm{N}$ and $\mathrm{Na}^{+}$at Mitra.

Table 4 - Average maize grain production $\left(\mathrm{g} \mathrm{m}^{-2}\right)$ at Alvalade and Mitra experimental fields. The values in brackets are the

\begin{tabular}{|c|c|c|c|c|c|c|c|}
\hline \multirow[t]{3}{*}{ Groups } & \multirow[t]{3}{*}{ Treatments } & \multicolumn{6}{|c|}{ Average grain production $\left(\mathrm{g} \mathrm{m}^{-2}\right)$} \\
\hline & & \multicolumn{2}{|c|}{$2004^{\mathrm{a}}$} & \multicolumn{2}{|c|}{2005} & \multicolumn{2}{|c|}{2006} \\
\hline & & Alvalade & Mitra & Alvalade & Mitra & Alvalade & Mitra \\
\hline \multirow[t]{3}{*}{ I } & A & 1008.9 & 1184.4 & $778.4(0.0)$ & $471.8(72.4)$ & 818.8 (45.9) & 892.1 (80.4) \\
\hline & B & 927.3 & 902.0 & 1069.9 (239.1) & $566.1(55.5)$ & $1212.1(76.2)$ & 866.8 (172.2) \\
\hline & C & 1223.2 & 866.7 & $1093.8(2.2)$ & $681.8(103.2)$ & $911.2(150.4)$ & $758.2(136.0)$ \\
\hline \multirow[t]{3}{*}{ II } & A & 1388.5 & 970.6 & 866.3 (130.2) & $467.1(91.3)$ & $830.2(54.3)$ & 886.1 (37.2) \\
\hline & B & 1270.6 & 1180.7 & $1103.4(126.0)$ & $583.6(97.9)$ & $1103.2(101.8)$ & $1051.9(65.4)$ \\
\hline & C & 1244.8 & 1128.9 & $1023.3(120.6)$ & $634.2(87.7)$ & $1212.5(244.2)$ & 1028.9 (91.6) \\
\hline \multirow[t]{3}{*}{ III } & A & 1353.9 & 1116.1 & $772.7(222.8)$ & $563.8(65.2)$ & $822.9(64.1)$ & 759.3 (128.8) \\
\hline & B & 1140.1 & 976.7 & $1014.6(308.6)$ & $630.2(63.1)$ & $1022.1(139.0)$ & 654.3 (101.6) \\
\hline & C & 821.1 & 683.7 & 947.2 (91.6) & $663.0(62.3)$ & $1116.9(139.2)$ & $988.5(93.1)$ \\
\hline \multirow[t]{3}{*}{ IV } & A & 1063.4 & 538.6 & $773.2(115.6)$ & $375.2(40.3)$ & $722.5(82.8)$ & 394.7 (55.6) \\
\hline & B & 734.8 & 705.1 & 728.5 (187.5) & $471.5(66.4)$ & $897.5(44.4)$ & 428.7 (16.5) \\
\hline & C & 715.5 & 758.7 & $780.2(96.6)$ & $516.3(39.6)$ & 823.4 (41.4) & $484.9(0.0)$ \\
\hline
\end{tabular}
standard deviation of the three repetitions.

a The standard deviation values of the 2004 maize production are not presented because in the first year, the three lines were harvested together. In the following years they were harvested separately. 

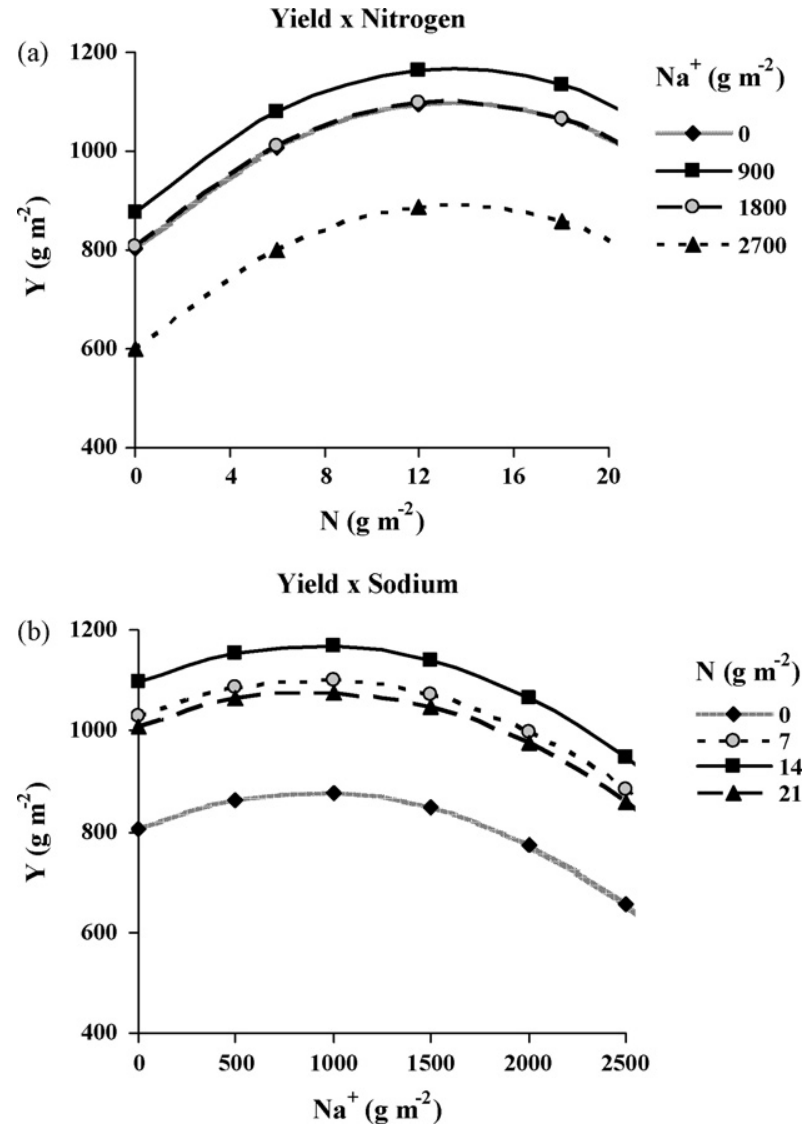

Fig. 3 - Grain production curves with decreasing returns to nitrogen (a), and to sodium (b), at Alvalade. Response measured while maintaining all other input factors constant.

\subsection{Yield response curves on both locations}

The result of the multiple stepwise regression analysis between grain yield $(\mathrm{Y})$ and the input factors nitrogen $(\mathrm{N})$, salt $\left(\mathrm{Na}^{+}\right)$, water $(\mathrm{W})$, and their interactions for all experimental data set (Alvalade and Mitra) for the period of 20042006 was established as:

$$
\begin{aligned}
\mathrm{Y}= & 681.87+66.91 \text { Year }+46.63 \mathrm{~N}-1.7382 \mathrm{~N}^{2}-0.5353 \mathrm{Na}^{+} \\
& -0.000102\left(\mathrm{Na}^{+}\right)^{2}+0.000719 \mathrm{~W} \mathrm{Na}^{+}-100.62 \text { Soil }
\end{aligned}
$$

The analysis of variance for Eq. (8) presents a SSR of $3.145 \times 10^{6}$, a SSE of $1.165 \times 10^{6}$, a $R^{2}$ of 0.730 , a $F$-value of 24.67, and $P<0.0001$ for $n=72$ observations. Fig. 5 shows the response curves of yield to different levels of $\mathrm{N}$ and $\mathrm{Na}^{+}$ considering all data from both experimental fields.

\section{Discussion}

\subsection{Analysis of yield response curves at Alvalade}

For the field experiment carried out in the textured medium Eutric Fluvisol of Alvalade, the adjustments to Eq. (6) were statistically significant. The model explains $62 \%$ of the
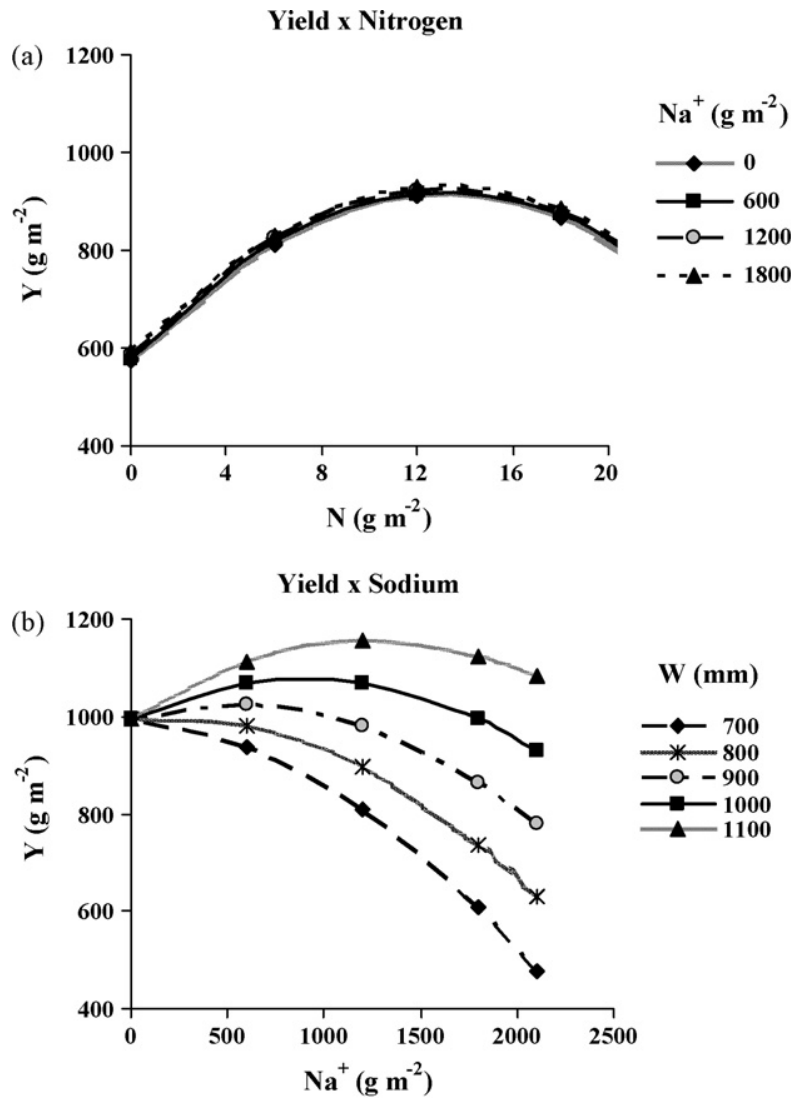

Fig. 4 - Grain production curves with decreasing returns to nitrogen (a), and to sodium (b), at Mitra. Response measured while maintaining all other input factors constant.

observed variations, with a total of 36 observations analysed. The effect of different years was only significant in the variability of mean annual yield. No significant interaction was found between nitrogen and sodium indicating that yield response to one of the input factors is not dependent on the other factor. Beltrão et al. (1993) studying the combined effects of $\mathrm{N}$ and salinity on sweet corn growth also found no interaction between these two input factors, when applying combined gradients of salinity (1-6.2 $\mathrm{dS} \mathrm{m}^{-1}$ ) and $\mathrm{N}$ fertilization (0-6.4 $\mathrm{g} \mathrm{m}^{-2}$ ). Pang and Letey (1998) using a combined plant-N-salinity-water response model (ENVIRO-GRO) and similar irrigation rates as in this study $(1050 \mathrm{~mm})$, also found no interactions between $\mathrm{N}$ and salinity due to high levels of deep percolation resulting in higher salt and nitrogen leaching. With more moderate irrigation rates $(630 \mathrm{~mm})$, they found a significant interaction between salinity and nitrogen, with high-salinity waters affecting $\mathrm{N}$ uptake and crop yield. Shenker et al. (2003) reported that $\mathrm{N}$ and salinity were inversely related (when salinity increases $\mathrm{N}$ uptake decreases).

Regression analysis shows that the yield response curves to $\mathrm{N}$ and $\mathrm{Na}^{+}$are quadratic, with diminishing response for each incremental change of the analysed variable factor. Each additional unit of input adds less to the total output than the previous unit does. Taking the partial derivate of the multiple regression equation (6) with respect to nitrogen $(\mathrm{N})$ yields: 

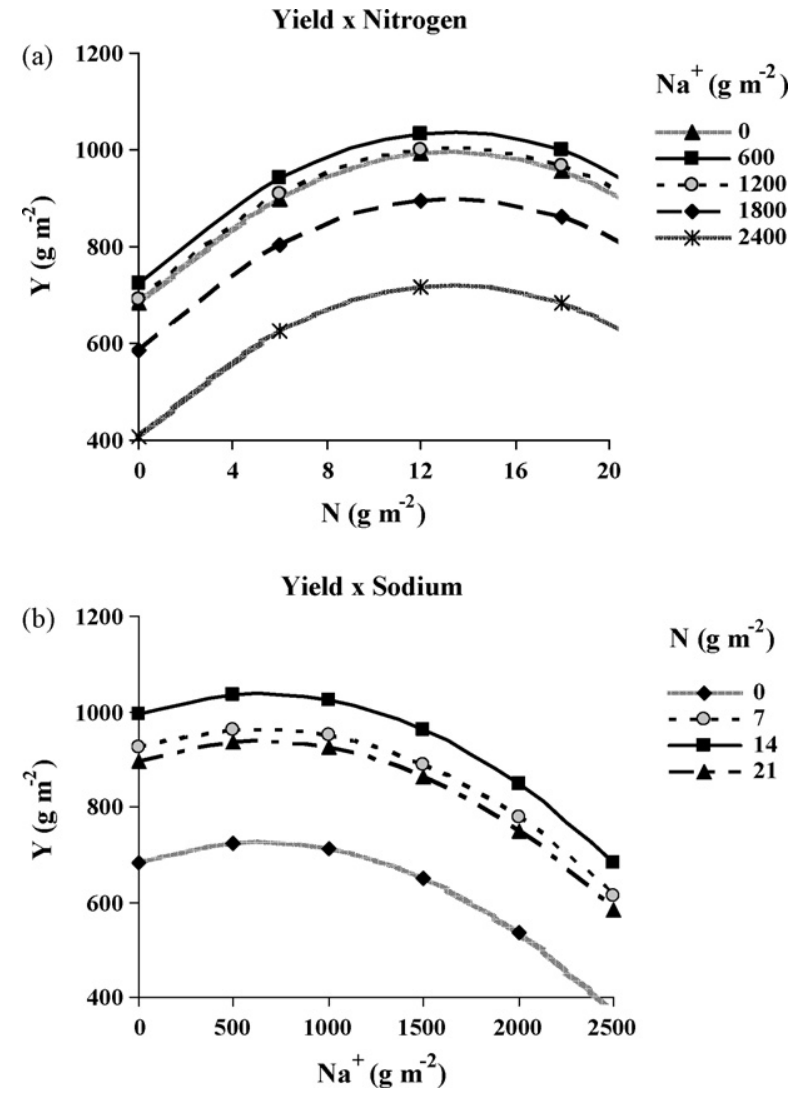

Fig. 5 - Grain production curves with decreasing returns to nitrogen (a), and to sodium (b), in production fields at Alvalade and Mitra. Response measured while maintaining all other input factors constant.

$\frac{\partial \mathrm{Y}}{\partial \mathrm{N}}=43.35-3.215 \mathrm{~N}$

Eq. (9) shows the decrease in yield per unit increase in nitrogen levels. The data shows that increasing nitrogen application indefinitely will not result in a direct increase in production. By equating nitrogen application to zero and solving for $\mathrm{N}$, the maximum yield $(\mathrm{Y})$ was determined to be obtained for $13.48 \mathrm{~g} \mathrm{~m}^{-2}$ of $\mathrm{N}$. This value is considerably lower than the $29.59 \mathrm{~g} \mathrm{~m}^{-2}$ of $\mathrm{N}$ obtained by Ramos et al. (1996) for the same soil and the same amount of water. When using only good quality waters and a $\mathrm{N}$ range of $26.0-30.0 \mathrm{~g} \mathrm{~m}^{-2}$, as recommended by the Portuguese Ministry of Agriculture (Dias, 2000), an acceptable crop yield was achieved in the same soil unit. Similarly Shenker et al. (2003) analysed different models describing the relationships between $\mathrm{N}$ fertilization and water salinity on yield response of sweet corn plants. The resultant response curves suggest lower demand for $\mathrm{N}$ at increasing salinity levels.

Likewise, taking the partial derivate of the multiple regression equation (6) with respect to sodium $\left(\mathrm{Na}^{+}\right)$yields

$\frac{\partial \mathrm{Y}}{\partial \mathrm{Na}^{+}}=0.1575-0.000174 \mathrm{Na}^{+}$

Eq. (10) shows that total yield increases at a decreasing rate per unit increase in the $\mathrm{Na}^{+}$level. The maximum yield is obtained when the total applied $\mathrm{Na}^{+}$equals $905.17 \mathrm{~g} \mathrm{~m}^{-2}$. Adding more sodium to the irrigation water will lead to yield reductions. Possible exchange reactions between $\mathrm{N}-\mathrm{NH}_{4}{ }^{+}$and $\mathrm{Na}^{+}$in the exchange complex cation of the soil may help explaining why the maximum yield was obtained when the total applied $\mathrm{Na}^{+}$ was of $905.17 \mathrm{~g} \mathrm{~m}^{-2}$ instead of $0 \mathrm{~g} \mathrm{~m}^{-2}$. This phenomenon seems to be associated with the gradual exchange of adsorbed ion $\mathrm{NH}_{4}{ }^{+}$in the soil for a monovalent cation provided with the irrigation water. This observation is in agreement with the reports of Nommik and Vahtras (1982), Drury and Beauchamp (1991), and Green et al. (1994). These authors studied fixation and release of $\mathrm{NH}_{4}{ }^{+}$in different soils when adding $\mathrm{K}^{+}$to the soil solution. Singh et al. (1969) suggested that depending on the existing salt concentration the effects of adding $\mathrm{Na}^{+}$was similar to $\mathrm{K}^{+}$. According to those studies and the obtained results in this study, $\mathrm{N}-\mathrm{NH}_{4}$ fixation in clay minerals provides protection against its lixiviation and provides a gradual release to plants throughout the vegetation cycle, at a rate dependent on the exchange of $\mathrm{Na}^{+}$with $\mathrm{NH}_{4}^{+}$:

Clay $\mathrm{Na}+\mathrm{NH}_{4}{ }^{+} \leftrightarrow$ Clay $\mathrm{NH}_{4}+\mathrm{Na}^{+}$

The exchange relation, expressed in Eq. (11), explaining the importance of low sodium content in irrigation waters on yields, is only briefly mentioned in the literature (Evangelou, 1998; Evangelou and Lumbanraja, 2002) and needs further study. However, previous studies suggest that fixation and release of $\mathrm{NH}_{4}{ }^{+}$within a growing season is important in many agricultural soils (Green et al., 1994). The rate of fixation and release of $\mathrm{NH}_{4}{ }^{+}$in the Eutric Fluvisol of Alvalade should be studied in the future. Another possible explanation is a reduction of nitrification of $\mathrm{N}-\mathrm{NH}_{4}$ to $\mathrm{N}-\mathrm{NO}_{3}$ due to the increase of salinity as described by McClung and Frankenberger (1987) and Irshad et al. $(2005,2008)$ with consequent $\mathrm{N}$ losses through leaching.

\subsection{Analysis of yield response curves at Mitra}

In the field experiment conducted in the coarse textured Hortic Anthrosol of Mitra, the adjustments to Eq. (7) were statistically significant with the model explaining $72 \%$ of the observed variation with a total of 36 observations analysed. Interactions between years and treatments also were not statistically significant in the experimental field data. The effect of the different years was again only significant in the variability of the mean annual yield. At Mitra the interaction between $\mathrm{N}$ and $\mathrm{Na}^{+}$was also not statistically significant, indicating that nitrogen was ineffective in counteracting the adverse effects on yield from high concentrations of sodium in the irrigation water.

Regression analysis results show that yield response curves are quadratic for $\mathrm{N}$ indicating diminishing yield returns for this factor. Taking the partial derivate of the multiple regression equation (7) with respect to nitrogen $(\mathrm{N})$ yields:

$\frac{\partial \mathrm{Y}}{\partial \mathrm{N}}=51.55-3.9124 \mathrm{~N}$

Eq. (12) shows the decrease in yield per unit increase in nitrogen levels. The results are similar to Alvalade. Yield decreases with each unit increase in the level of nitrogen. Maximum yield is obtained for a level of $\mathrm{N}$ of $13.18 \mathrm{~g} \mathrm{~m}^{-2}$. This 
value is slightly lower than the $17.14 \mathrm{~g} \mathrm{~m}^{-2}$ of $\mathrm{N}$ found by Ramos et al. (1996) for a similar soil and the same amount of water, but using fresh water. The maximum yield is also lower than the range of $17.0-22.0 \mathrm{~g} \mathrm{~m}^{-2} \mathrm{~N}$ recommended by the Portuguese Ministry of Agriculture as an amount for an acceptable crop yield in this type of soil also when using waters of good quality (Dias, 2000). The model obtained at Mitra suggests a lower demand for $\mathrm{N}$ at increasing salinity levels, in accordance with Shenker et al. (2003). Similarly, no interaction (positive or negative) was found between those two input factors. The results from Mitra were different from Alvalade, in that yield was not affected by changes in the level of $\mathrm{Na}^{+}$. Yield was only responsive to water as the partial derivate of the multiple regression equation (7) expressed with respect to sodium $\left(\mathrm{Na}^{+}\right)$, demonstrate:

$$
\frac{\partial \mathrm{Y}}{\partial \mathrm{Na}^{+}}=-0.5898+0.000649 \mathrm{~W}
$$

Eq. (13) suggests that the sandy loam textural class of the Hortic Antrosol at Mitra, with its lower water retention capacity and higher saturated hydraulic conductivity, was favourable to sodium leaching with each irrigation event. This resulted in a low sodium concentration in the soil profile throughout the irrigation seasons and did not negatively affect yield. Nevertheless, the results also show that a substantial increase in the concentration of sodium in the irrigation water would require an ever-increasing depth of water to maintain the same yields. Letey et al. (1985), Bresler (1987), Beltrão and Ben Asher (1997), and Pang and Letey (1998) have also shown that salt stress can be ameliorated by additional irrigation water. Richards (1954) recommended increasing the amount of water when using waters of worse quality in order to prevent soil salinization/sodification and achieve higher crop yields. However, Shani and Dudley (2001) report that the critical irrigation level decreased with increasing salinity, thus demonstrating that additional water did not compensate for salt stress. In their work, a decrease in maximum yield was associated with decreased transpiration. The result was that less irrigation was required to produce the highest yield at a given salinity level.

\subsection{Analysis of mean yield response curves on both locations}

By combining the data set of Alvalade and Mitra, the adjustments proved to be statistically significant, with the model explaining $73 \%$ of the total observed variations. Furthermore, the model included all the trends verified in the analysis of each individual experimental field. The regression result shows that yield response curves to $\mathrm{N}$ and $\mathrm{Na}^{+}$are quadratic indicating, as in Alvalade, diminishing returns to the two variable factors. Taking the partial derivate of the multiple regression equation (8) with respect to nitrogen (N) yields:

$$
\frac{\partial \mathrm{Y}}{\partial \mathrm{N}}=46.63-3.4762 \mathrm{~N}
$$

showing that the rate of yield decreases per unit change in nitrogen level, with the maximum yield being achieved at a level of $13.41 \mathrm{~g} \mathrm{~m}^{-2}$ of $\mathrm{N}$. This result is identical to the $\mathrm{N}$ application required at Alvalade and Mitra. The partial derivate of the multiple regression equation (8) with respect to sodium $\left(\mathrm{Na}^{+}\right)$:

$$
\frac{\partial \mathrm{Y}}{\partial \mathrm{Na}^{+}}=-0.5353-0.000204 \mathrm{Na}^{+}+0.000719 \mathrm{~W}
$$

reflects the difference in behaviour between Alvalade and Mitra when taking into account the effect of sodium on yield. Indeed, the rate of yield decreased per unit change in $\mathrm{Na}^{+}$level, reaching its maximum at $629.10 \mathrm{~g} \mathrm{~m}^{-2}$ of $\mathrm{Na}^{+}$in the irrigation water when considering the mean amount of irrigation water applied on both sites during the 3 years of the experiment $(923 \mathrm{~mm})$. Combining all data and observing that $\mathrm{Na}^{+}$and $\mathrm{W}$ in Eq. (15) have opposite signs, the results show that, similar to Mitra, when the sodium concentration of the irrigation water is increased higher water depths will be required to maintain the yield at similar levels.

\section{Conclusions}

The models obtained from the multiple stepwise regression analysis of grain yield $(\mathrm{Y})$ and the input factors nitrogen $(\mathrm{N})$, sodium $\left(\mathrm{Na}^{+}\right)$, water $(\mathrm{W})$ and their interactions explained 62 and $72 \%$ of the total observed variation at Alvalade and Mitra, respectively.

For both experimental sites, yield increases at a decreasing rate per unit change in the $\mathrm{N}$ level. The yield response to $\mathrm{N}$ application diminishes as $\mathrm{N}$ level increases. Maximum yield is obtained by applying $13 \mathrm{~g} \mathrm{~m}^{-2} \mathrm{~N}$. Increasing $\mathrm{N}$ application above this level will not result in an increase in yield.

At the medium textured soil of Alvalade, yield response to $\mathrm{Na}^{+}$application also diminishes with increased $\mathrm{Na}^{+}$. A maximum yield was achieved at $905.17 \mathrm{~g} \mathrm{~m}^{-2}$ of $\mathrm{Na}^{+}$application. This useful effect of irrigation water salinity could be due to the displacement and subsequent availability for the crop of $\mathrm{NH}_{4}{ }^{+}$adsorbed in the soil exchange complex but displaced by increased concentrations of $\mathrm{Na}^{+}$. In the coarse textured soil of Mitra, yields are not affected by changes in $\mathrm{Na}^{+}$level. They respond solely to changes in the level of the input water. In addition, the use of irrigation waters with higher sodium content at Mitra will require the use of more water to maintain yield at the same level as when irrigating with low sodium waters.

The combined results from both sites embody the same trends observed in each individual site, including the positive effect of sodium on maize yield when small amounts up to $630 \mathrm{~g} \mathrm{~m}^{-2}$ are in the irrigation water.

\section{Acknowledgements}

This work was possible due to the funding provided by the Project PTDC/AGR-AAM/66004/2006 of the Fundação para a Ciência e a Tecnologia and the Project AGRO 727 of the Portuguese Ministry of Agriculture, Fisheries, and Rural Development. 


\section{R E F E R E N C E S}

Allen, R.G., Pereira, L.S., Raes, D., Smith, M., 1998. Crop evapotranspiration-guidelines for computing crop water requirements. Irrig. Drain. Pap. 56. FAO, Rome, Italy.

Ayers, R., Westcot, D., 1985. Water quality for agriculture. Irrig. Drain. Pap. 29. FAO, Rome, Italy.

Beltrão, J., Ben Asher, J., Magnusson, D., 1993. Sweet corn response to combined effects of saline and nitrogen fertilization. Acta Hortic. 335, 53-58.

Beltrão, J., Ben Asher, J., 1997. The effect of salinity on corn yield using the CERES-maize model. Irrig. Drain. Syst. 11, 15-28.

Beltrão, J., Jesus, S.B., Panagopoulos, T., Ben Asher, J., 2002a. Combined effects of salts and nitrogen on the yield function of lettuce. Acta Hortic. 573, 363-368.

Beltrão, J., Jesus, S.B., Silva, V., Sousa, P.B., Carvalho, I., Trindade, D., Rodrigues, M.H., Machado, A., 2002b. Efficiency of triple emitter source (TES) for irrigation experiments of horticultural crops. Acta Hortic. 573, 183-188.

Bresler, E., 1987. Application of a conceptual model to irrigation water requirement and salt tolerance of crops. Soil Sci. Soc. Am. J. 51, 788-793.

Brumbelow, K., Georgakakos, A., 2007. Determining crop-water production functions using yield-irrigation gradient algorithms. Agric. Water Manage. 87, 151-161.

Datta, K.K., Sharma, V.P., Sharma, D.P., 1998. Estimation of a production function for wheat under saline conditions. Agric. Water Manage. 36, 85-94.

de Malach, Y., Ben Asher, J., Sagih, M., Alert, A., 1996. Doubleemitter source (DES) for irrigation experiments in salinity and fertilization. Agron. J. 88, 987-990.

Dias, J.S., 2000. Manual de Fertilização das Culturas. Laboratório Químico Agrícola Rebelo da Silva, Instituto Nacional de Investigação Agrária, Lisboa, Portugal.

Dinar, A., Rhoades, J.D., Nash, P., Waggoner, B.L., 1991. Production functions relating crop yield, water quality and quantity, soil salinity and drainage volume. Agric. Water Manage. 19, 51-66.

Drury, C.F., Beauchamp, E.G., 1991. Ammonium fixation, release, nitrification, and immobilization in high and lowfixing soils. Soil Sci. Soc. Am. J. 55, 125-129.

Duque, J., Almeida, C., 1998. Caracterização hidroquímica do sistema aquífero dos Gabros de Beja. In: Proceedings of the 4th Congress of Water. Lisbon, 23-27 de Março (CR-ROM).

Evangelou, V.P., 1998. Environmental Soil and Water Chemistry. Principles and Applications. John Wiley \& Sons, p. 564.

Evangelou, V.P., Lumbanraja, J., 2002. Ammonium-potassiumcalcium exchange on vermiculite and hydroxy-aluminum vermiculite. Soil Sci. Soc. Am. J. 66, 445-455.

Flores, P., Carvajal, M., Cerda, A., Martinez, V., 2001. Salinity and ammonium/nitrate interactions on tomato plant development, nutrition, and metabolites. J. Plant Nutr. 24, 1561-1573.

Grattan, S.R., Grieve, C.M., 1999. Salinity-mineral nutrient relations in horticultural crops. Sci. Hortic. 78, 127-157.

Green, C.J., Blackmer, A.M., Yang, N.C., 1994. Release and fixed ammonium during nitrification in soils. Soil Sci. Soc. Am. J. 58, 1411-1415.

Hanks, R.J., Keller, J., Rasmussen, V.P., Wilson, G.D., 1976. Line source sprinkler for continuous variable irrigation-crop production studies. Soil Sci. Soc. Am. J. 40, 426-428.

Hillel, D., 1998. Environmental Soil Physics. Academic Press, p. 771.

Igbadun, H.E., Tarimo, A.K.P.R., Salim, B.A., Mahoo, H.F., 2007. Evaluation of selected crop water production functions for an irrigated maize crop. Agric. Water Manage. 94, 1-10.
Irshad, M., Honna, T., Yamamoto, S., Eneji, A.E., Yamasaki, N., 2005. Nitrogen mineralization under saline conditions. Commun. Soil Sci. Plant Anal. 36 (11), 1681-1689.

Irshad, M., Eneji, A.E., Yasuda, H., 2008. Comparative effect of nitrogen sources on maize under saline and non-saline conditions. J. Agron. Crop Sci. 194 (4), 256-261.

Kant, S., Kant, P., Lips, H., Barak, S., 2007. Partial substitution of $\mathrm{NO}_{3}{ }^{-}$by $\mathrm{NH}_{4}{ }^{+}$fertilization increases ammonium assimilating enzyme activities and reduces the deleterious effects of salinity on the growth of barley. J. Plant Physiol. 164, 303-311.

Keren, R., 2000. Salinity. In: Summer, M.E. (Ed.), Handbook of Soil Science. CRC Press, Boca Raton, FL, pp. G1-G26.

Kipkorir, E.C., Raes, D., Massawe, B., 2002. Seasonal water production functions and yield response factors for maize and onion in Perkerra, Kenya. Agric. Water Manage. 56, 229240.

Lauer, D.A., 1983. Line-source sprinkler system for experimentation with sprinkler-applied nitrogen fertilizers. Soil Sci. Soc. Am. J. 47, 124-128.

Letey, J., Dinar, A., Knapp, K.C., 1985. Crop-water production function model for saline irrigation waters. Soil Sci. Soc. Am. J. 49, 1005-1009.

Levy, Y., Columbus, D., Sadan, D., Lifshitz, J., 1999. Trickle linear gradient for assessment of the salt tolerance of citrus rootstocks in the orchards. Irrig. Sci. 18, 181-184.

Liu, W.-Z., Zhang, X.-C., 2007. Optimizing water and fertilizer input using an elasticity index: a case study with maize in the Loess plateau of China. Field Crops Res. 100, 302-310.

Magnusson, D.A., Ben Asher, J., De Malach, Y., 1989. A continuous two-variable design using the line-source concept. Agron. J. 81, 132-133.

Magnusson, D.A., Ben Asher, J., 1990. Simulated water and solute distribution from a crossed triple line source. Irrig. Sci. 11, 31-36.

Makus, D.J., 2003. Salinity and nitrogen levels can affect the agronomic performance, leaf color and mineral nutrients of vegetable amaranth. Subtrop. Plant Sci. 55, 1-6.

Mass, E.V., 1990. Crop salt tolerance. In: Tanji, K.K. (Ed.), Agricultural Salinity Assessment and Management. Manual Eng. Pract., 71, 13. Am. Soc. Civ. Eng., Reston, VA, pp. 262-304.

McClung, G., Frankenberger Jr., W.T., 1987. Nitrogen mineralization rates in saline vs. salt-amended soils. Plant Soil 104, 13-21.

Nommik, H., Vahtras, K., 1982. Retention and fixation of ammonium and ammonia in soils. In: Stevenson, F.J. (Ed.). Nitrogen in Agricultural Soils. Agronomy, vol. 22. Am. Soc. of Agronomy, Madison, WI, U.S.A., pp. 123-171.

Oliveira, I., Varela, M., 2005. A qualidade da água dos pequenos regadios individuais do Alentejo. In: Proceedings of the I National Congress of Irrigation and Drainage. Beja, Portugal, December 5-8 (CD-ROM).

Pang, X.P., Letey, J., 1998. Development and evaluation of ENVIRO-GRO, an integrated water, salinity, and nitrogen model. Soil Sci. Soc. Am. J. 62, 1418-1427.

Papadopoulos, I., Rending, V.V., 1983. Interactive effects of salinity and nitrogen on growth and yield of tomato plants. Plant Soil 73 (1), 47-57.

Ramos, J.B., Oliveira, A.J., Fernandes, M.L., 1996. Optimização da eficiência da rega em ensaios nas culturas do milhoforragem, milho-grão, beterraba, tomate e batata. Agronomia Lusitana 45 (4), 359-386.

Richards, L.A., 1954. Diagnosis and Improvement of Saline and Alcaly Soils. USDA Handbook 60. United States Department of Agriculture, WA, U.S.A.

Sandoval-Villa, M., Wood, C.W., Guertal, E.A., 1999. Effects of nitrogen form, nighttime nutrient solution strength, and 
cultivar on greenhouse tomato production. J. Plant Nutr. 22, 1931-1945.

Shani, U., Dudley, L.M., 2001. Field studies of crop response to water and salt stress. Soil Sci. Soc. Am. J. 65, 1522-1528.

Shenker, M., Ben-Gal, A., Shani, U., 2003. Sweet corn response to combined nitrogen and salinity environmental stresses. Plant Soil 256, 139-147.

Singh, B.R., Agarwal, A.S., Kanehiro, Y., 1969. Effect of chloride salts on ammonium nitrogen release in two Hawaiian soils. Soil Sci. Soc. Am. Proc. 33, 557-560.
Steppuhn, H., van Genuchten, M.T., Grieve, C.M., 2005. Rootzone salinity. II. Indices for tolerance in agricultural crops. Crop Sci. 45, 221-232.

Villa-Castorena, M., Ulery, A.L., Catalán-Valencia, E.A., Remmenga, M.D., 2003. Salinity and nitrogen rate effects on the growth and yield of Chile pepper plants. Soil Sci. Soc. Am. J. 67, 1781-1789.

WRB, 2006. World reference base for soil resources. A framework for international classification, correlation and communication. World Soil Resources Reports 103. Food and Agriculture Organization of the United Nations, Rome. 